\title{
Developing children's motor skills in the Foundation Phase in Wales to support physical literacy
}

Nalda Wainwright, Jackie Goodway, Amanda John, Kirsty Thomas, Kate Piper, Kate Williams \& David Gardener

To cite this article: Nalda Wainwright, Jackie Goodway, Amanda John, Kirsty Thomas, Kate Piper, Kate Williams \& David Gardener (2019): Developing children's motor skills in the Foundation Phase in Wales to support physical literacy, Education 3-13, DOI: 10.1080/03004279.2019.1633374

To link to this article: https://doi.org/10.1080/03004279.2019.1633374

曲 Published online: 23 Jun 2019.

Submit your article to this journal

View Crossmark data $₫$ 


\title{
Developing children's motor skills in the Foundation Phase in Wales to support physical literacy
}

\author{
Nalda Wainwright ${ }^{\mathrm{a}}$, Jackie Goodway ${ }^{\mathrm{b}}$, Amanda Johnc, Kirsty Thomas ${ }^{\mathrm{a}}$, Kate Piper ${ }^{\mathrm{c}}$, \\ Kate Williams ${ }^{c}$ and David Gardener ${ }^{c}$ \\ ${ }^{a}$ Wales Institute for Physical Literacy, University of Wales Trinity Saint David, Carmarthen, Wales, UK; ${ }^{b}$ Department of \\ Human Sciences, The Ohio State University, Columbus, OH, USA; ' University of Wales Trinity Saint David, Carmarthen, \\ Wales, UK
}

\begin{abstract}
Interest has grown internationally in the concept of physical literacy [Dudley, D. 2015. "A Conceptual Model of Observed Physical Literacy." The Physical Educator 72: 236-260; Edwards, L., A. Bryant, R. Keegan, K. Morgan, and A. Jones. 2017. "Definitions, Foundations and Associations of Physical Literacy: A systematic Review." Sports Medicine 47 (1): 113-126] acknowledging holistic embodied learning. This notion of embodied learning resonates with the play based approach of the Foundation Phase in Wales for children aged 3-7. With early childhood being the optimum age for developing Fundamental Motor skills, the primary purpose of this paper is to describe a programme (SKIP-Cymru) for developing pupils' motor skills in the Foundation Phase. Drawing on Successful Kinaesthetic Instruction for Pre-schoolers (SKIP) [Goodway, J. D., and C. F. Branta. 2003. "Influence of a Motor Skill Intervention on Fundamental Motor Skill Development of Disadvantaged Preschool Children." Research Quarterly for Exercise and Sport 74 (1): 36-46] and playful pedagogy [Howard, J., and K. Mclnnes. 2010. "Thinking Through the Challenge of a Play-based Curriculum, Increasing Playfulness via Co-construction." In Thinking about play, edited by J. R. Moyles. Berkshire: Open University Press], SKIP-Cymru combines advocacy with leadership, training and mentoring for staff and parental engagement. Early exploratory data from an initial evaluation suggest SKIP-Cymru is a positive experience for staff and parents which improves pupils' motor competence in both locomotor and object control skills. Limitations of the research design are discussed along with implications for future research.
\end{abstract}

\section{ARTICLE HISTORY}

Received 28 November 2018

Accepted 7 June 2019

\section{KEYWORDS}

Motor development; physical literacy; play; early childhood; physical development

\section{Introduction}

\section{Physical literacy}

Growing interest in the concept of physical literacy has led to developing definitions throughout the world with most recognising embodiment and the holistic lifelong aspects of the concept (Dudley 2015; Edwards et al. 2017; Jurbula 2015; Whitehead 2010). Whitehead dissatisfied with 'what she considered the dominant, dualist tendencies' of physical education (Standal 2015, 24) drew on the work of the existentialist Merleau-Ponty to advocate for a 'monist or holistic view of the human condition' recognising 'the centrality of our embodiment in existence and our nature as essentially beings-in-the world' (Whitehead 2007, 283). As such she suggests that humans 'create themselves as they interact with their surroundings' (Whitehead 2010,26) and this is no more evident than in early childhood 
where, as Ayres $(2005,7)$ explains, mental and social functions are 'based upon a foundation of sensory motor processes.' She suggests there is better development of higher intellectual functions 'if the sensory motor functions are well developed' (24) and advocates that 'seven or eight years of moving and play are required to give the child a sensory motor intelligence that can serve as the foundation for intellectual, social and personal development' (Ayres 2005, 25). Movement and play in early childhood is also an important factor in the development physical competence, an attribute of physical literacy (Whitehead 2010), with research identifying early childhood as the optimal time for the development of motor competence serving as the foundation for later physical activity (Barnett, Salmon, and Hesketh 2016; Barnett et al. 2016; Clark and Metcalf 2002; Seedfelt 1980; Stodden et al. 2008). This is of particular importance in light of Whitehead's definition of physical literacy that includes 'to value and take responsibility for engagement in physical activities for life' (International Physical Literacy Association 2017). The importance of movement in early childhood resonates strongly with the Welsh Foundation Phase, which is a play-based curriculum for children aged 3-7years. The Foundation Phase advocates a balance between adult-led learning and childled activities allowing teachers to work on focussed learning as well as allowing children to play (Wainwright et al. 2016). Although the Foundation Phase is a play-based curriculum it is not free play per se and the approach could best be described as playful pedagogy. However, despite having adult-led physical development sessions and an active play-based approach, which could indicate ample opportunities for the development of motor competence, research into the implementation of this curriculum in relation to physical literacy found children were not developing all aspects of their motor skills due to a lack of teacher expertise (Wainwright et al. 2018). In response to these findings, and as part of the Welsh Governments Physical Literacy Programme for Schools (PLPS), the Wales Institute for Physical Literacy (WIPL) implemented a programme of training and mentoring in schools in West Wales. Drawing on Successful Kinaesthetic Instruction for Pre-schoolers (SKIP) (Goodway and Branta 2003) and the notion of playful pedagogy (Howard and Mclnnes 2010) the programme, known as SKIP-Cymru (Cymru is the Welsh word for Wales), aims to develop practitioners' expertise in motor skill instruction and embed this within the playful pedagogy of the Foundation Phase. Our purpose in this paper is primarily to outline the programme of SKIP-Cymru as an example of translational practice and secondarily to present early exploratory data from initial implementation of SKIP-Cymru as part of the Physical Literacy Programme for Schools. Firstly we will give an overview of the Foundation Phase and playful pedagogy giving the context and rationale for SKIP-Cymru. Secondly, we will outline SKIP-Cymru, its underpinning theories and key features and finally present initial exploratory data assessing early implementation of the programme.

\section{The Foundation Phase}

The Foundation Phase is underpinned by childhood well-being and was influenced by international curricula such as Reggio Emilia in Northern Italy, Te Whariki in New Zealand, Hi-Scope in the USA and the Forest Schools in Scandinavia (Wyn Siencyn 2015). Features from these open curricula can be seen in the Foundation Phase with its child-centred play-based approaches incorporating active learning and use of the outdoors as central to pupils' experiences. From the time of early educational pioneers and theorists such as Rousseau, Dewey, Froebel, Montessori, MacMillan and Steiner, play has been recognised as having an important role in children's early education (Wood and Attfield 2005). Chazan $(2002,198)$ identifies the value of play in developing self-awareness claiming 'play activity reflects the very existence of the self, that part of the organism that exists both independently and interdependently, that can reflect upon itself and be aware of its own existence'. This development of self-awareness is an important aspect of child development that both contributes to physical literacy, and is an outcome of physical literacy. Maude $(2010,111)$ highlights the important relationship between play and physical literacy as play 'facilitates the establishment of many of the other attributes that are characteristic of a physically literate individual, including motivation, confidence, environmental and interpersonal engagement, self-knowledge and self-expression.' 
As a play-based curriculum the interpretation of play in the Foundation Phase is not clearly defined and is problematic as 'play is always context dependent' (Wood and Attfield 2005, 5). A multitude of definitions of play abound in the literature and definitions are variously based on criteria, category or continuum (Pellegrini 1991; Piaget 1951; Rubin, Fein, and Vandenberg 1983). Play itself can be in many different forms such as role play, imaginative play, free flow or structured to name but a few, however in the context of the Foundation Phase Pellegrini's $(1991,215)$ comments are perhaps the most useful suggesting 'Play can be categorised as 'more or less play', not dichotomous as 'play or not play.' This notion of a continuum of play works well for the Foundation Phase where children move from adult-led activities to more freely chosen tasks. Even many of the teacher-led tasks are playful in their nature. With such an emphasis on play in the Welsh curriculum, an understanding of the concept of play is central to how it is interpreted in the school context. Teachers' pedagogical foundations are reflected in the value they place on play and thus the opportunities they provide for the pupils to play (Sandberg and Heden 2011, 1). Definitions of play have tended to be adults' perceptions based on what they observe of children playing (Howard 2002, b34). However, Mclnnes et al. (2011) studied children's approaches to activities and proposed that children make their own distinctions between work and play. They propose utilising a concept of play which is based on children's perceptions highlighting playfulness as an approach and attitude to an activity may help to develop practitioners understanding of play (Howard and Mclnnes 2010). Howard and Mclnnes's $(2010,35)$ work highlights how children use cues to make the distinction between work and play illustrated in Table 1.

In the playful pedagogical approach of the Foundation Phase activities often have cues children associate with play, such as being physical, not at a desk and an aspect of choice and autonomy. Links are well documented between play, intrinsic motivation, task engagement and deeper involvement in the learning (Brock 2009; Howard and Mclnnes 2010; Mclnnes et al. 2011; Moyles 2010). Although the Foundation Phase is a play-based curriculum, there are still focussed taught sessions, and with physical development as an area of learning teachers still take classes for structured physical activities in the school hall or outside, but in addition to this, the playful pedagogy of the Foundation Phase means that children are seldom sitting at desks to learn. Mathematical development is more likely to be a maths trail around the school grounds than worksheets at a table. Language development could be a spelling game on a big chalk board in the playground or hunting for letters in the sand pit. These types of activities mean that children are developing their physical skills throughout all of their learning and sedentary time is kept to a minimum. When we consider this from a physical literacy perspective, drawing on existentialism, the active play-based learning environment of the Foundation Phase should be an ideal context to promote physical literacy, where children 'create themselves as they interact with their surroundings' (Whitehead 2010, 26). However, although Wainwright et al. (2018) found the Foundation Phase made a positive contribution to the development of physical literacy, 'in terms of pupils' motor development there was no significant improvement in object control skills' (441).

From a developmental perspective a lack of development of pupils' object control skills is a cause for concern for several reasons. Ensuring children develop fundamental motor skills (FMS) in early childhood is important if they are to be able to access a range of physical activity opportunities throughout life (Seedfelt 1980; Clark and Metcalfe 2002; Stodden et al. 2008; Barnett, Salmon, and

Table 1. Cues that children use to distinguish between play and work.

\begin{tabular}{|c|c|c|c|}
\hline $\begin{array}{l}\text { Play } \\
\text { Emotional cues }\end{array}$ & Environmental cues & $\begin{array}{l}\text { Work } \\
\text { Emotional cues }\end{array}$ & Environmental cues \\
\hline Voluntary & On the floor & Compulsory & At a table \\
\hline Under child's control & $\begin{array}{l}\text { Lacks adult involvement } \\
\text { No adult evaluation }\end{array}$ & Under adult control & $\begin{array}{l}\text { Includes adult involvement } \\
\text { Includes adult evaluation }\end{array}$ \\
\hline Easy & $\begin{array}{l}\text { Can be continued-focus on the process } \\
\text { Physical }\end{array}$ & Hard & Has to finish-focus on the product \\
\hline Fun & & Can be fun & Not physical \\
\hline
\end{tabular}


Hesketh 2016; Barnett et al. 2009, 2016). Evidence from the field of motor development highlights the importance of developing FMS which requires underlying attributes that are 'fundamental' aspects of coordination and control for many types and forms of movements (Barnett et al. 2013). Stodden et al. (2008) highlight the complex relationship between physical activity, motor competence and perceived physical competence in early childhood. The psychological effects of perceiving oneself to be a competent mover impacts on an individual's desire to engage in physical activities (Barnett et al. 2016; Stodden et al., 2008; Robinson et al. 2015). Although the development of physical competence, and within this fundamental motor skills, is not in itself the development of physical literacy, motor skills are an important component of physical competence, which Whitehead $(2010,14)$ identifies along with motivation, confidence and effective interaction with the environment, as an attribute of physical literacy. Research suggests that fundamental motor skills are associated with and predictive of physical activity, fitness, healthy weight status and cognitive and academic outcomes (Holfelder and Schott 2014; Lubans et al. 2010; Haapala 2013). Of particular concern in relation to the Foundation Phase in Wales is that children who are proficient in object control skills in primary (elementary) school are most likely to become active and fit adolescents (Barnett et al. 2008, 2009).

It has been contended that FMS are acquired naturally through play (Almond 2014; Pot and van Hilvoorde 2014), however despite many of these opportunities being available in the Foundation Phase pupils did not develop ontogenetic FMS (Gallahue, Ozmun, and Goodway 2012). This supports the argument that these skills need to be taught with children needing higher levels of instruction to master the complex movements required to perform complex skills in a combination of instruction, modelling and practice (Barnett et al. 2013; Gallahue, Ozmun, and Goodway 2012; McKenzie et al. 1998). With the limited hours of physical education training in initial teacher education (Seedfelt 1980 ) it would seem that teachers in primary schools lack the necessary knowledge and understanding to facilitate pupils' development of object control skills.

The misconception that children acquire these skills naturally through play may derive from differences in society in the past. Children in the past would play outside for extended periods of time after school and during weekends. This play would often have been with children of mixed age groups, older neighbours, cousins and siblings exposing them to other children's perspectives, becoming 'experts for one another, scaffolding their own and peers' learning experiences' Broadhead (2006, 202). More recent changes in society such as risk aversion, working parents with busy lifestyles, a lack of green space, coffee shop culture and the growth of screen time have created a 'perfect storm' of inactivity with children spending extended periods of time in sedentary behaviours inside and disengaged from nature (Gill 2007; Louv 2008; Seedfelt 1980; The Guardian 2016; Wainwright 2017). The consequences of this are manifesting themselves in the classrooms of the Foundation Phase. Children are starting school with poor core stability, poor balance, a lack of strength and coordination. Increasing numbers of children are presenting with problems associated with co-ordination disorders due to a lack of movement in the pre-school years and this is an issue that goes beyond physical activity as movement in early childhood is important for the development of the whole child (Ayres 2005; Kirby and Drew 2003; Goddard Blythe 2005, 2013).

\section{The development of SKIP-Cymru}

Dudley et al. (2017) highlight the need for policy makers to consider the development of physical literacy at a more strategic level and in 2015 the Welsh Government funded Physical Literacy Programme for Schools (PLPS) enabled The Wales Institute for Physical Literacy to develop an approach in the region that could address the issue of pupils' motor development in the Foundation Phase. The PLPS was a targeted initiative, working only with Challenge Cymru schools identified as Wales' 'most challenged schools' (Williams 2017) 'from disadvantaged backgrounds' (Welsh Government 2017, 3) where children are more likely to have developmental delays in their motor development (Goodway and Branta 2003). A range of pedagogical approaches have been developed that support the acquisition of motor skills and in particular, approaches that use mastery and non-threatening, non- 
competitive, autonomous climates to promote learning (Edvardsson et al. 2011). One such approach developed by Goodway and colleagues is Successful Kinaesthetic Instruction for Pre-schoolers (SKIP). This has been successful with remediating motor skill delays, in particular with children in areas of socio-economic deprivation, such as the schools in the PLPS (Goodway and Branta 2003; Goodway et al. 2013; Robinson and Goodway 2009). There have been many published studies using SKIP and this strong evidence base made it an appropriate programme to use in the development of work in the PLPS (Brian et al. 2017; Goodway and Branta 2003; Goodway, Crowe, and Ward 2003; Goodway and Robinson 2006; Robinson and Goodway 2009).

The SKIP program is situated within Dynamic Systems Theory (DST) (Thelen, Kelso, and Fogel 1987) and Newell's constraints theoretical framework (Newell 1984, 1986) along with being rooted in physical education pedagogy best practices. The SKIP program accommodates individual constraints by modifying equipment and designing developmentally appropriate tasks that align with the child's current level of motor development with a focus on maximum opportunities to respond, correct practice trials and time on task placing the child in an optimal environment to promote their motor skill development (Brian, Goodway, and Sutherland 2014).

Therefore, in light of the need to develop object control skills for pupils in the Foundation Phase in Wales, SKIP was incorporated into the playful pedagogy of the Foundation Phase and a programme of professional development SKIP-Cymru implemented in the PLPS schools in the region. SKIP-Cymru needed to fit with the play-based, holistic nature of the Foundation Phase and as such was developed to incorporate cross-curricular opportunities to integrate motor development. Drawing on the work of Howard and McInnes (2010) and recognising cues children associate with play SKIP-Cymru was developed to align with the playful pedagogy of the Foundation Phase in both focussed physical development sessions and also across all areas of learning.

A challenge for the development of SKIP-Cymru was that Foundation Phase staff would need to be able to deliver the approach. SKIP was originally delivered by experts in motor skill development, however later studies showed that early childhood teachers were also able to deliver a programme of SKIP that was highly effective in improving pupils FMS in as little as eight weeks (8-12 weeks, 360420 min) (Brian, Goodway, and Sutherland 2014; Goodway and Branta 2003; Robinson and Goodway 2009). As part of the PLPS, SKIP-Cymru had to incorporate key Welsh Government targets of parental engagement and be sustainable. Therefore the approach that has been developed is a cross-sector collaboration working with regional sports development teams and leisure services to develop a whole school and community approach, resulting in a programme with several key features.

\section{SKIP-Cymru key features}

(1) Advocacy with leadership

(2) SKIP-Cymru training day for Foundation Phase staff

(3) SKIP-Cymru mentoring

(4) Parental engagement

(5) Not resource-driven

(6) Advocacy with leadership

Fullan (2016) after decades of study of the process of educational change highlights that change fails when it is not consistent across layers, so a teacher cannot sustain change working in a negative school culture, and a school cannot sustain change in an unsupportive district. Edvardsson et al. (2011) support this highlighting the need for not only involving frontline professionals in intervention development but that success of a programme depends on managerial support and an overall supportive system. Therefore, a key element in the implementation of SKIP-Cymru is support at all levels. As such a programme of advocacy is carried out in a region prior to starting the training. Presentations are given to regional advisors support schools and all head teachers in the region. This ensures that school leaders are aware of physical literacy and the issues identified in relation to young 
children's motor competence in the Foundation Phase. Staff coming on the training days can then be assured of support for the approach on returning to their schools.

\section{SKIP-Cymru training day}

The training day combines theory and practice in relation to physical literacy, the importance of movement and motor competence in child development. Teachers knowing the theoretical basis for the work is crucial as without 'knowledge about why they are doing what they're doing, implementation will be superficial only' (McLaughlin and Mitra 2000, 10). Investment in teachers' professional development is widely recognised in relation to successful change in schools. SKIP-Cymru aims for two members of staff from each school to be trained in order to build a learning culture (Fullan 2016) where the teachers collectively develop and support each other. Cole (2012 24) explains how this 'promotes increased feelings of teacher efficacy, increased student engagement and improves pupil outcomes' which is ultimately the aim of SKIP-Cymru.

Practical sessions on the training day involve staff learning the importance of developing a broad movement vocabulary for pupils and understanding strategies and activities to facilitate this back in school. Staff are then taught to recognise developmental stages of FMS and explore how they can manipulate task and environmental factors to enable pupils to progress to proficiency. Staff carry out workshop tasks to assess their levels of understanding and working in groups develop activities that they can use back in their schools immediately after the training. The workshop incorporates two elements of SKIP-Cymru firstly structured physical development sessions focussing on developing pupils' skills and secondly cross-curricular opportunities to include SKIP-Cymru elements in activities across all areas of learning as playful pedagogy.

\section{SKIP-Cymru mentoring}

It is widely recognised that one-day professional development training approaches are unlikely to change practice, with professional development needing to be collaborative, on-going and embedded in context (Armour et al. 2015; Hunzicker 2011). Therefore, in addition to the SKIPCymru training day a system of mentoring supports staff back in their schools. Mindful of the need to be cost-effective and sustainable, mentors are identified in the regional sports development teams that already worked with schools in the region. The mentors are trained with SKIP-Cymru attending several training days with staff they will be mentoring. In schools they deliver at least one session of mentoring per week for 6-8 weeks, modelling activities and co-delivering with staff that have been on the training.

\section{Parental engagement}

An important aspect to developing sustainable change is the need for developing school connectedness as part of the wider community (Rowe and Stewart 2009) and Dudley et al. (2017) highlight the need to address issues of power at a strategic level. Inclusive strategies are needed that encourage active participation of community members and equal power relationships and partnerships with community members (Rowe and Stewart 2009).

Working with parents and the community is an important aspect of SKIP-Cymru. Parents have the majority of control over their children's physical activity opportunities and in order to ensure that children are able to be more physically active throughout all aspects of their lives parents need to be made aware of the importance of movement for their children's development. The parental engagement aspect of the work combines two approaches. Teachers invite parents and younger siblings into school for active family sessions where they are shown ideas and activities to develop motor competence. Parent bags are also sent home with the children for a week at a time. These are small bags containing some simple equipment and ideas and an active family booklet for recording the activities the children do at home with their family using the equipment. The bags rotate around the children in the class so ideas are shared and parents continue to be reminded of the importance of movement. The children are not the only people to benefit from this aspect of SKIP-Cymru, with parents having 
developed their confidence and taking over the running of the after school active family sessions (Milford Mercury 2017).

\section{Not resource-driven}

A key element of the cost-effectiveness of the approach is that it does not have costly resources alongside the training. Rather the approach is one that aims to ensure the staff are able to understand how to use a range of resources that are already available. This allows flexibility in the approaches that schools use to deliver SKIP-Cymru utilising resources and the environment that is available in their own school context. Teachers cannot rely on prepared lesson plans but have use what they have learned on the training and mentoring as such developing their professional capacity, which Fullan (2016) highlights as a feature of successful schools.

The current political climate remains one of data and accountability however with the increasing interest in the concept of physical literacy there are 'concerns about its practical application' (Dudley et al. 2017, 437). In developing SKIP-Cymru our purpose is foremost practical application in order to change practice across the region. Although our aim is primarily changing teachers practice, it is important to ascertain whether SKIP-Cymru is able to impact pupils' motor skills in Wales similarly to SKIP in the USA. Therefore, an initial evaluation of the early implementation of SKIP-Cymru was carried out in the PLPS schools in the region. This initial evaluation aimed to address two research questions;

(1) Can a programme of SKIP-Cymru develop pupils' motor skills?

(2) What are the staff and parents' experiences of SKIP-Cymru?

The following section outlines the procedures carried out to address these questions and reports the findings from this early data.

\section{Method}

\section{Settings and participants}

A total of 12 classes from 10 schools participated in the evaluation of the SKIP-Cymru programme. The 10 schools were PLPS schools and the delivery of SKIP-Cymru was a means to support the development of physical literacy. Therefore the training for staff was the main priority and as such control (wait) groups for the evaluation were only possible in two schools which had parallel classes in their Foundation Phase settings.

\section{Design and intervention}

A total of $164(M$ age $=5.53$ years SD \pm 0.62$)$ Foundation Phase pupils were tested in the 10 schools prior to the staff attending the SKIP-Cymru training. All pupils from the ten experimental classes $(n=$ 134) received an 8-week programme of SKIP-Cymru comprising of $2 \times 45 \mathrm{~min}$ per week as per previous SKIP interventions (Brian, Goodway, and Sutherland 2014; Goodway and Branta 2003; Robinson and Goodway 2009). The first of the two sessions was with the support of a mentor and the second with the class teacher. In some cases the school hall was not available for two whole class session so teachers were asked to use small groups and cross curricular delivery to make up the equivalent of a second 45-minute session. The pupils from the two control (wait) classes $(n=21)$ had no SKIP-Cymru sessions, but continued with the normal business as usual Foundation Phase provision. The post-test was administered to all pupils $(n=164)$ after 8 weeks. Following this for ethical reasons the control (wait) classes received 8 weeks of SKIP-Cymru with mentoring. During the 8 weeks of SKIP-Cymru Teachers ran the parental engagement sessions after school or lunch time. The children then were able to borrow an equipment bag (parent bag) to take home and practice activities and record this in an active family booklet. 


\section{Instrumentation}

The dependent variable for the evaluation was pupils' motor skills which were assessed using the Test of Gross Motor Development version 3 (TGMD-3) (Ulrich 2016). The TGMD-3 is a process-orientated assessment which assesses the gross motor performance of young children, aged 3-10 years which consists of a selection of locomotor skills and ball skills that represent fundamental motor skills that are commonly taught in primary physical education curriculum on an international scale (Ulrich 2016). International normative data for the TGMD-3 was under review at the time of the evaluation so TGMD-3 standard scores, percentiles, age-equivalent scores, and gross motor quotient scores could not be used for analysis in this study. Therefore, participants' TGMD-3 locomotor and ball skills subtest raw scores, and overall gross motor performance raw scores were interpreted as the principal dependent variables. TGMD-3 was administered by post-graduate students of physical education who had received training to ensure that standardised procedures for the TGMD-3 were followed for all participants. All tests were video recorded for coding and inter-rater reliability at pretest $(97.6 \%)$, post-test (98\%) and retention test (97.5\%). Statistical Package for the Social Sciences (SPSS, software version 24.0, IBM Corp, 2016) was used to perform statistical analysis.

Semi-structured interviews were conducted with heads, teachers, teaching assistants and parents from the schools $(n=11)$ to gain an insight into the wider experiences of the schools implementing SKIP-Cymru.

Qualitative data was generated with the use of semi-structured interviews. The semi-structured nature of the interviews allowed freedom to clarify participants understanding, follow up issues at greater depth, and explore viewpoints that were not foreseen (Newby 2010). A framework of questions enabled the interviews to generate data that would explore the experience of SKIP-Cymru but still allow for expansion of issues (see the Appendix). Respondent validation was conducted to ensure trustworthiness. Interviews were transcribed and analysed using the constant comparative method of inductive data analysis (Maykut and Morehouse 1994). This process involved the identification of units of meaning within the data. These were compared to other units and where similarities occurred, grouped into clusters of relevant meaning. From these clusters of relevant meaning, categories and themes emerged.

\section{Results}

\section{Quantitative data}

To address research question one and ascertain whether a programme of SKIP-Cymru develops pupils' motor skills, the percentage change in TGMD-3 raw scores were calculated for each pupils' total score, the locomotor subset and object control subset. The percentage change was used due to the mixture of ages of the pupils and multiple classes in the programme. Percentile scores could not be calculated for the pupils as norms for the TGMD-3 were not yet available. Percentage change for pupils' raw scores prior to SKIP-Cymru and post-intervention were calculated.

\section{Total scores}

Pupils who took part in SKIP-Cymru saw an average 35\% (SD $\pm 19 \%$ ) improvement in their TGMD-3 total raw score compared to $3 \%(S D \pm 25 \%)(C l 0.27,0.46)$ in the control/wait group. An independent samples $t$-test was used to compare the mean percentage change of the experimental and control groups. A significant difference $[t(162)=7.84, p<0.001]$ was found between the SKIP-Cymru pupils and control/wait group pupils (Figure 1).

\section{Locomotor scores}

Pupils who took part in SKIP-Cymru saw an average 31\% (SD $\pm 23 \%$ ) improvement in their TGMD-3 locomotor raw score compared to $0 \%(S D \pm 33 \%)(C l 0.20,0.42)$ in the control/wait group. An 


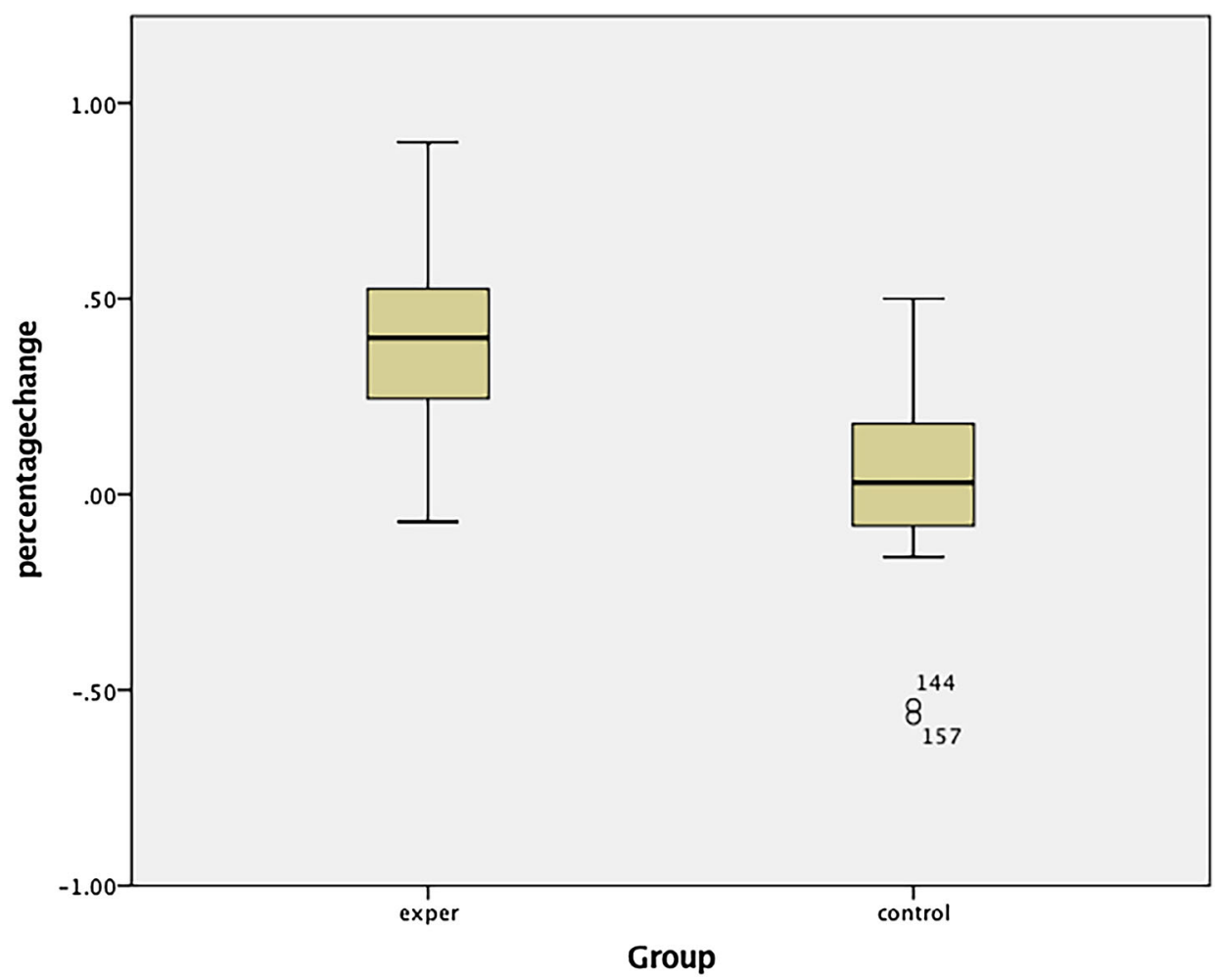

Figure 1. Mean percentage change in pupils total TGMD-3 raw scores.

independent samples $t$-test was used to compare the mean percentage change of the experimental and control groups. A significant difference $[t(162)=5.34, p<0.001]$ was found between the SKIPCymru pupils and control/wait group pupils (Figure 2).

\section{Object control skills}

Pupils who took part in SKIP-Cymru saw an average 49\% (SD $\pm 27 \%$ ) improvement in their TGMD-3 locomotor raw score compared to $4 \%(\mathrm{SD} \pm 48 \%)(\mathrm{Cl} 0.30,0.59)$ in the control/wait group. An independent samples $t$-test was used to compare the mean percentage change of the experimental and control groups. A significant difference $[t(162)=6.21, p<0.001]$ was found between the SKIPCymru pupils and control/wait group pupils (Figure 3 ).

\section{Discussion}

These findings suggest that SKIP-Cymru may make a significant impact on both locomotor skills and object control skills of pupils in the Foundation Phase, however, limitations of the study need consideration. It should be noted that the primary intention of the project was to develop SKIP-Cymru and in so doing, implement professional development for teachers for the Physical Literacy Programme for Schools (PLPS). The generation of data to evaluate this work was a secondary intention. As such even though the schools were all in similar areas of socio-economic deprivation, the numbers and ages of pupils in classes varied and only two classes were available to be control (wait) groups. All findings should be considered with these factors in mind.

Analysis of the initial exploratory data indicates that the SKIP-Cymru pupils made significantly greater improvements in both their locomotor skills and object control skills than the control 


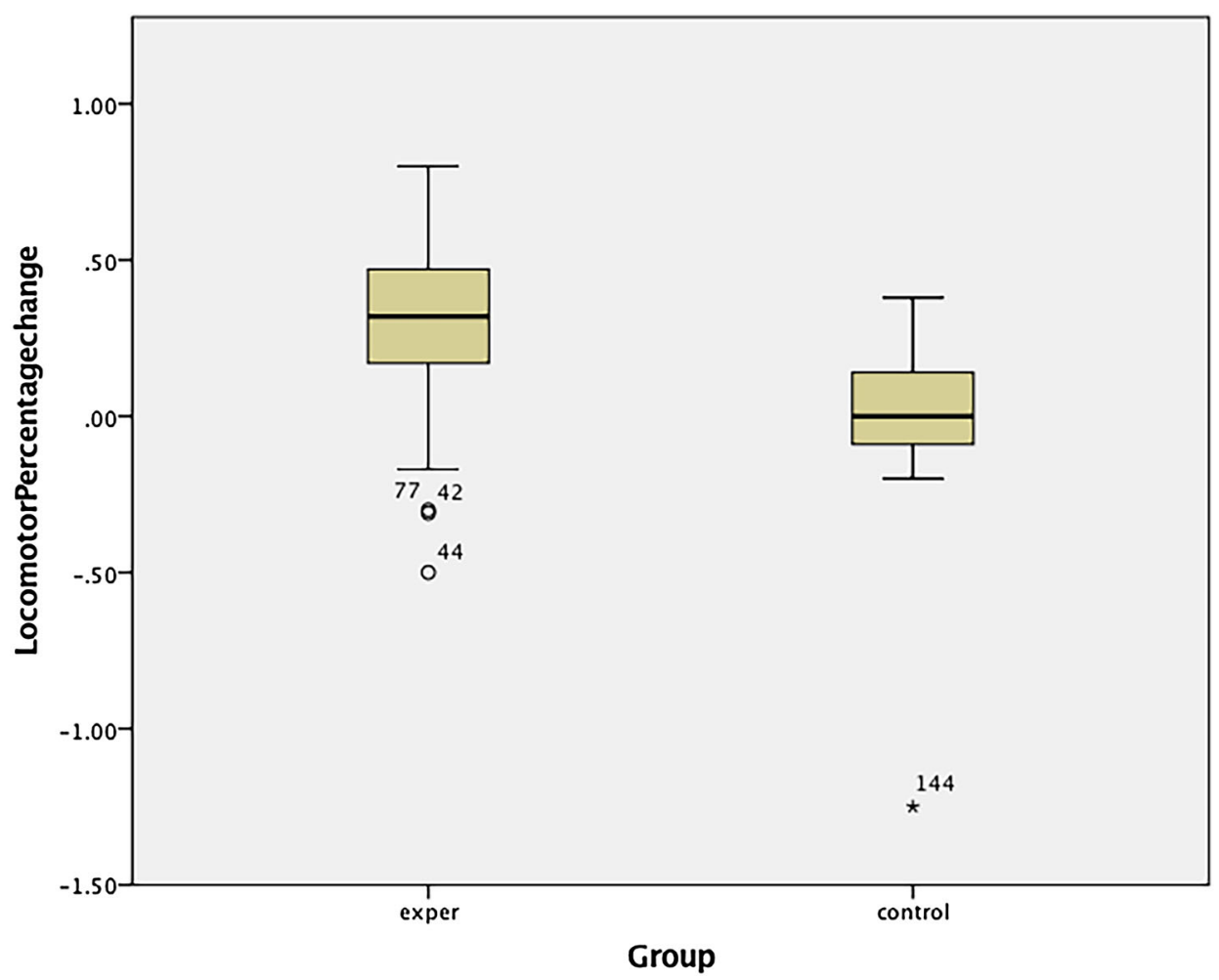

Figure 2. Mean percentage change in pupils' TGMD-3 locomotor raw scores.

(wait) pupils. Of particular note is the SKIP-Cymru pupils made improvements of $49 \%$ compared to $4 \%$ in the control pupils. As the original intention of SKIP-Cymru was to address the issue of a lack of development of object control skills in the Foundation Phase this may suggest that SKIP-Cymru could be an effective approach for remediating this issue. However, this study has highlighted another possible concern in that the control pupils on average made no improvement in their locomotor skills. Previously research indicated that the active and play-based nature of the Foundation Phase was improving this aspect of pupils' FMS (Wainwright et al. 2018). This raises questions about whether delivery of the Foundation Phase has changed, or whether behaviour changes at home and in society are reducing the physical activity which is needed for the development of these phylogenetic skills (Gallahue, Ozmun, and Goodway 2012). More robust research is needed to explore this issue.

An issue of interest is the outliers in both groups that appear to make little or no progress and even regress. This may indicate that these pupils could have more complex developmental issues in relation to motor development and further assessments of pupils would be useful in individual cases. Qualitative data could be used to understand reasons for outliers in the data, however qualitative data in this project was focussed on the experiences of the staff and parents, and as such did not explore the development of individual pupils. Future research could include this aspect in order to shed light on anomalies in pupil scores.

A further limitation of this study that needs consideration is in relation to fidelity of implementation. Although mentors were trained to support the delivery of SKIP-Cymru in the schools there was no staff capacity to assess fidelity in settings. The nature of the Foundation Phase and the cross-curricular aspect of SKIP-Cymru delivery makes this particularly challenging and needs to be addressed in future research. As normative data for TGMD-3 becomes available future research can standardise results by student age and therefore more robust data analysis can be conducted. 


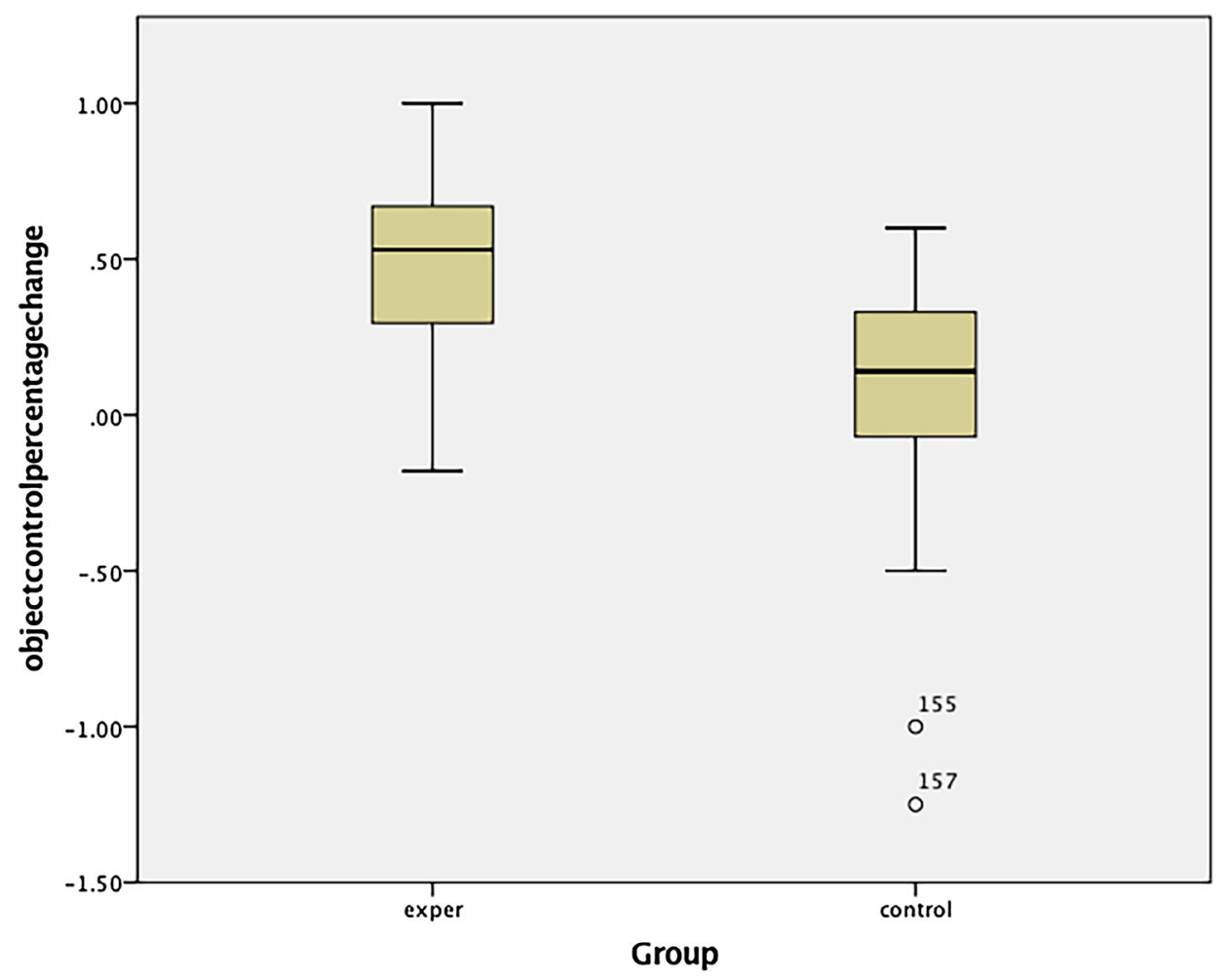

Figure 3 Mean percentage change in pupils' TGMD-3 object control raw scores.

\section{Qualitative data}

Analysis of qualitative data (as outlined previously) identified five main themes:

(1) Impact on pupils

(2) Impact on staff

(3) Variety of activities in the school and home

(4) School ethos

(5) Staff support

\section{Impact on pupils}

Staff perceived pupils to be more engaged, motivated and showing better outcomes as a result of the increased structured movement opportunities. Existing research highlights the relationship between physical competence and confidence (Goodway and Branta 2003; Stodden et al. 2008) the staff comments indicate they felt this was apparent for the children in their classes 'We have seen a huge improvement in gross motor skills and this has supported the development of their fine motor skills' (interview 3), 'huge improvements in the children's concentration, focus and engagement in the classroom, I can see their confidence is getting better all the time' (interview 7), 'the confidence in my children to watch them grow is amazing' (interview 16).

\section{Impact on staff}

Staff commented on how they felt the training had developed their understanding as it 'shone a light on that there's more to it than what we've been, you know, providing' (interview 2). In particular the 
way they noticed children moving, 'I've got to say it opened my eyes to the way children play, totally like I came back and was thinking God, you know I looked at kids in totally a different way you know just seeing them playing in the yard or just little things in the classroom' (interview 10).

\section{Variety of activities in home and school}

The staff were particularly positive about the parental engagement element of the programme, commenting on the impact that it had on the children 'they loved having the parents there and showing them what to do' ... . 'all the parents really enjoyed it' (interview 8). The parents also reflected on the parental engagement aspect of the programme, their children's enjoyment and the confidence they felt it gave them 'I took one of those home (parental bag) because l've got 4 girls and they all joined in, my daughter was in nursery and she picked it up just by doing it with her sister' (interview 9). It was apparent that for some parents this was the first time they had engaged with opportunities in the school and it for one in particular it had initiated new activities for the family,

'SKIP-Cymru was the first club we come to and we really enjoyed it its really fun. Its good interaction between me and my children. We do a lot of throwing and catching and counting' 'they are doing a lot more throwing and kicking and playing football, they're doing a lot more of that which they never used to, they've even started playing golf over the field you know they've got a couple of clubs and see how many hits they can do you know, they never used to do these activities' (interview 4).

\section{School ethos}

Head teachers worked with staff and parents to develop a school ethos that valued and supported physical activity.

well I have seen the impact on the pupils and the parents and we are developing more opportunities for children to move. We've developed an area in the grounds as a climbing and active space for the children to play in before and after school, we've put tables there for mums to watch their children, it encourages them to stay longer. (interview 1)

Heads and staff worked to overcome barriers 'We don't have a hall at present due to building work so we have groups doing their SKIP stuff all over the corridors, well, really in any space we can find' (interview 5).

\section{Staff support}

Teachers valued the support of other staff to help them as they developed their confidence 'it was good as there were two of us doing this together, we could discuss ideas and think of activities' (interview 10). Sometimes the support was for staff who had not attended the training

I get to work with head of nursery and head of reception once a week, so we sit down and we look at their planning, and look at which aspects we can make more physical' 'it's really interesting because it was little tweaks and they were like "I would never of thought of doing that" so it's really helped and they're all really excited. (interview 5)

They also commented on the support of the mentoring, 'it's good knowing someone is coming in to help, especially at the start when we weren't sure if we were doing the right things' (interview 11).

Although qualitative data suggest that staff and parents felt the experience of SKIP-Cymru was a positive one there were however some comments that indicate aspects need more consideration in future developments. Parental engagement sessions were not consistently attended 'sometimes we have a big turnout, but sometimes there are only a couple, it's frustrating' (interview 10). 'some of the parents are not keen to join in and we have to work to persuade them sometimes' (interview 7). One of the Head teachers stressed the importance of parental engagement

I notice the difference with parents, some of whom will talk to me where as in the beginning they would just walk past me. I would say hello and smile and they would nod but wouldn't speak, now they speak and even volunteer on occasions. (interview 2) 
However she highlights the work this took 'but that has taken a lot, a lot of work with (the class teacher)(name removed) to actually get those parents to that position' (interview 2). This is an area that needs developing if there is to be sustained connectedness to the wider community of the schools (Rowe and Stewart 2009) and the importance of this work is summed by the Head 'I really wanted to engage with the families because you can impact so much with the children but really, it's the families we need to get to because that's where it will truly be sustainable' (interview 2).

\section{Conclusion}

This paper outlined the rationale for and development of SKIP-Cymru. The paper discussed how the evidence-based programme of SKIP (Goodway and Branta 2003) and playful pedagogy (Howard and McInnes 2010) were influential in the development of this programme in a way that would fit with the Foundation Phase approach. Data from an early exploratory evaluation of SKIP-Cymru was reported with the limitations of this first data generation highlighted. The results of this early evaluation suggest that this programme was a positive experience for staff and parents and could result in improvements in pupils' motor competence in both locomotor and object control skills. More robust research is required to assess the impact of SKIP-Cymru. Further studies developing work with parents and families is needed to identify strategies for consistent parental engagement.

\section{Disclosure statement}

No potential conflict of interest was reported by the authors.

\section{References}

Almond, L. 2014. "Serious Flaws in an FMS Interpretation of Physical Literacy." Science and Sports 29 (Suppl.): S60. doi:10. 1016/j.scispo.2014.08.121.

Armour, K., M. Quennerstedt, F. Chambers, and K. Makopulou. 2015. "What is 'Effective' CPD for Contemporary Physical Education Teachers? A Deweyan Framework." Sport, Education and Society 16 (5): 571-591.

Ayres, J. A. 2005. Sensory Integration and the Child. Understanding Hidden Sensory Challenges. Los Angeles, CA: Western Psychological Services.

Barnett, L. M., T. Hinkley, A. D. Okely, and J. Salmon. 2013. “Child, Family and Environmental Correlates of Children's Motor Skill Proficiency." Journal of Science and Medicine in Sport 16 (4): 332-336.

Barnett, L., J. Salmon, and K. Hesketh. 2016. "More Active Pre-School Children Have Better Motor Competence at School Starting Age: An Observational Cohort Study." BMC Public Health 16 (1): 1-8.

Barnett, L., D. Stodden, K. Cohen, P. Morgan, D. Lubans, L. Matthieu, S. Livonen, et al. 2016. "'Fundamental Motor Skills: An Important Focus." Journal of Teaching in Physical Education 35 (3): 219-225.

Barnett, L., E. van Beurden, P. Morgan, L. Brooks, and J. Beard. 2008. " Does Childhood Motor Skill Proficiency Predict Adolescent Fitness?" Medicine and Science in Sports and Exercise 40 (12): 2137-2144.

Barnett, L., E. van Beurden, P. Morgan, L. Brooks, and J. Beard. 2009. " Childhood Motor Skill Proficiency as a Predictor of Adolescent Physical Activity." Journal of Adolescent Health 44 (3): 252-259.

Brian, A., J. Goodway, J. Logan, and S. Sutherland. 2017. "SKIPing with Head Start Teachers: Influence of T-SKIP on Object Control Skills." Research Quarterly for Exercise and Sport. Advance Online Publication. doi: 10.1080/02701367.2017. 1375077.

Brian, A. S., J. D. Goodway, and S. L. Sutherland. 2014. "Training Teachers to SKIP: A Motor Skill Intervention Pilot Study." Research Quarterly for Exercise and Sport 85 (S1): A42-A43.

Broadhead, P. 2006. "Developing an Understanding of Young Children's Learning Through Play: The Place of Observation, Interaction and Reflection." British Educational Research Journal 32 (2): 191-207.

Brock, A. 2009. "Curriculum and Pedagogy of Play: A Multitude of Perspectives?" In Perspectives on Play Learning for Life, edited by A. Brock, S. Dodds, P. Jarvis, and Y. Olusoga, 67-93. Harlow: Pearson.

Chazan, S. 2002. Profiles of Play: Assessing and Observing Structure and Process in Play Therapy. London: Jessica Kingsley.

Clark, J. E., and J. S. Metcalf. 2002. "The Mountain of Motor Development: A Metaphor." In Motor Development: Research and Review: Vol. 2, edited by J. E. Clark and J. H. Humphrey, 62-95. Reston, VA: NASPE.

Cole, P. 2012. Aligning Professional Learning, Performance Management and Effective Teaching. Seminar Series 217. Melbourne: Centre for Strategic Education.

Dudley, D. 2015. "A Conceptual Model of Observed Physical Literacy." The Physical Educator 72: 236-260. 
Dudley, D., J. Cairney, N. Wainwright, D. Kriellaars, and D. Mitchell. 2017. "Critical Considerations for Physical Literacy Policy in Public Health, Recreation, Sport and Education Agencies." Quest (Grand Rapids, Mich) 69 (4): 463-452.

Edvardsson, K., R. Garvare, A. Ivarsson, E. Eurenius, I. Mogren, and M. Nytrom. 2011. "Sustainable Practice Change: Professionals' Experiences with a Multi-Sectoral Child Health Promotion Programme in Sweden." BMC Health Sciences Research 11: 61. doi:10.1186/1472-6963-11-61.

Edwards, L., A. Bryant, R. Keegan, K. Morgan, and A. Jones. 2017. "Definitions, Foundations and Associations of Physical Literacy: A Systematic Review." Sports Medicine 47 (1): 113-126.

Fullan, M. 2016. The New Meaning of Educational Change. 5th ed. New York: Routledge.

Gallahue, D. L., J. C. Ozmun, and J. D. Goodway. 2012. Understanding Motor Development: Infants, Children, Adolescents and Adults. 7th ed. Boston, MA: McGraw-Hill.

Gill, T. 2007. No Fear: Growing up in a Risk Averse Society. London: Calouste Gulbenkian Foundation.

Goddard Blythe, S. 2005. The Well Balanced Child Movement and Early Learning. Gloucestershire: Hawthorn Press.

Goddard Blythe, S. 2013. "The Importance of Movement in Early Development - The Foundation of Developing Physical Literacy." ICSSPE Bulletin - Journal of Sport Science and Physical Education 65: 97-107.

Goodway, J. D., and C. F. Branta. 2003. "Influence of a Motor Skill Intervention on Fundamental Motor Skill Development of Disadvantaged Preschool Children." Research Quarterly for Exercise and Sport 74 (1): 36-46.

Goodway, J. D., A. Brian, S. H. Chang, R. Famelia, E. Suda, and L. E. Robinson. 2013. "'Promoting Physical Literacy in the Early Years Through Project SKIP.'" ICSSPE Bulletin - Journal of Sport Science and Physical Education 65: 121-129.

Goodway, J. D., H. Crowe, and P. Ward. 2003. "Effects of Motor Skill Instruction on Fundamental Motor Skill Development." Adapted Physical Activity Quarterly 20 (3): 298-314.

Goodway, J. D., and L. E. Robinson. 2006. "SKIPing Toward an Active Start: Promoting Physical Activity in Preschoolers." Beyond the Journal: Young Children 61 (3): 1-6.

The Guardian. 2016. "Three Quarters of Children Spend Less Time Outside Than Prison Inmates." https://www. theguardian.com/environment/2016/mar/25/three-quarters-of-uk-children-spend-less-time-outdoors-than-prisoninmates-survey.

Haapala, E. A. 2013. "Cardiorespiratory Fitness and Motor Skills in Relation to Cognition and Academic Performance in Children: A Review." Journal of Human Kinetics 36 (1): 5-189.

Holfelder, B., and N. Schott. 2014. "Relationship of Fundamental Movement Skills and Physical Activity in Children and Adolescents: A Systematic Review." Psychology of Sport and Exercise 15 (4): 382-391.

Howard, J. 2002. "Eliciting Young Children's Perceptions of Play, Work and Learning Using the Activity Apperception Story Procedure." Early Child Development and Care 172 (5): 489-502.

Howard, J., and K. McInnes. 2010. "Thinking Through the Challenge of a Play-Based Curriculum, Increasing Playfulness via Co-Construction." In Thinking About Play, edited by J. R. Moyles, 30-44. Berkshire: Open University Press.

Hunzicker, J. 2011. "Effective Professional Development for Teachers: A Checklist." Professional Development in Education 37 (2): 177-179.

International Physical Literacy Association (IPLA). 2017. https://www.physical-literacy.org.uk/.

Jurbula, P. 2015. "What is Physical Literacy Really?" Quest (Grand Rapids, Mich) 67 (4): 367-383.

Kirby, A., and S. Drew. 2003. Guide to Dyspraxia and Developmental Coordination Disorder. London: David Fulton.

Louv, R. 2008. Last Child in the Woods: Saving our Children From Nature-Deficit Disorder. Chapel Hill, NC: Algonquin Books.

Lubans, D. R., P. J. Morgan, D. P. Cliff, L. M. Barnett, and A. D. Okely. 2010. "Review of the Benefits Associated with Fundamental Movement Skill Competency in Youth." Sports Medicine 40 (12): 1019-1035.

Maude, P. 2010. "Physical Literacy and the Young Child." In Physical Literacy Throughout the Lifecourse, edited by M. E. Whitehead, 100-115. London: Routledge.

Maykut, P., and R. Morehouse. 1994. Beginning Qualitative Research: A Philosophic and Practical Guide. London: Routledge/ Falmer.

Mclnnes, K., J. Howard, G. Miles, and K. Crowley. 2011. “'Differences in Practitioners' Understanding of Play and How This Influences Pedagogy and Children's Perceptions of Play."' Early Years 31 (2): 121-133.

McKenzie, T. L., J. E. Alcaraz, J. F. Sallis, and F. N. Faucette. 1998. “Effects of a Physical Education Program on Children's Manipulative Skills." Journal of Teaching in Physical Education 17: 327-341.

McLaughlin, M., and D. Mitra. 2000. Contradictions of School Reform. London: Routledge.

Milford Mercury. 2017. http://www.milfordmercury.co.uk/news/15174501.milford-havens-meads-school-skip-project-ishelping-combat-sedentary-lifestyles-and-encourage-physical-learning/.

Moyles, J. 2010. The Excellence of Play. New York: McGraw-Hill International.

Newby, P. 2010. Research Methods for Education. London: Pearson Education.

Newell, K. M. 1984. "Physical Constraints to Development of Motor Skills." In Motor Development During Preschool and Elementary Years, edited by J. Thomas, 105-120. Minneapolis, MN: Burgess.

Newell, K. M. 1986. "Constraints on the Development of Coordination." In Motor Development in Children: Aspects of Coordination and Control, edited by M. G. Wade and H. T. A. Whiting, 341-360. Dordrecht: Nijhoff.

Pellegrini, A. D. 1991. Applied Child Study. Hillsdale, NJ: Lawrence Erlbaum.

Piaget, J. 1951. Play, Dreams and Imitation in Childhood. London: William Heinemann. 
Pot, N., and I. van Hilvoorde. 2014. "Fundamental Movement Skills do not Lead Necessarily to Sport Participation." Science and Sports 29 (Supplement): S60-S61.

Robinson, L. E., and J. D. Goodway. 2009. "Instructional Climates in Preschool Children who are At-Risk. Part I: ObjectControl Skill Development." Research Quarterly for Exercise and Sport 80 (3): 533-542.

Robinson, L. E., D. F. Stodden, L. M. Barnett, V. P. Lopes, S. W. Logan, L. P. Rodrigues, and E. D’Hondt. 2015. “Motor Competence and its Effect on Positive Developmental Trajectories of Health." Sports Medicine 45 (9): 1273-1284.

Rowe, F., and D. Stewart. 2009. "Promoting Connectedness Through Whole-School Approaches: A Qualitative Study." Health Education 109 (5): 396-413.

Rubin, K. H., G. Fein, and B. Vandenberg. 1983. "Play." In Handbook of Child Psychology: Vol 4. Socialization, Personality, and Social Development, edited by E. M. Hetherington, 751-760. New York: Wiley.

Sandberg, A., and R. Heden. 2011. "Play's Importance in School." Education 3-13 39 (3): 317-329.

Seedfelt, V. 1980. "The Concepts of Readiness Applied to Motor Skill Acquisition." In Children in Sport, edited by R. A. Magill, M. J. Ash, and F. L. Smoll, 281-296. Champaign, IL: Human Kinetics.

Standal, O. 2015. Phenomenology and Pedagogy in Physical Education. Oxon: Routledge.

Stodden, D., J. Goodway, S. Langendorfer, M. Roberton, M. Rudisill, C. Garcia, and L. Garcia. 2008. "A Developmental Perspective on the Role of Motor Skill Competence in Physical Activity: An Emergent Relationship." Quest (Grand Rapids, Mich) 60 (2): 290-306.

Thelen, E., J. A. S. Kelso, and A. Fogel,. 1987. "Self-organizing Systems and Infant Motor Development." Developmental Review 7: 39-65.

Ulrich, D. A. 2016. The Test of Gross Motor Development. 3rd ed. Austin, TX: Pro-ed. http://www.kines.umich.edu/tgmd3.

Wainwright, N. 2017. "Improving physical literacy to survive a 'perfect storm."' IPLC Keynote lecture. Toronto, April 2017.

Wainwright, N., J. Goodway, M. Whitehead, A. Williams, and D. Kirk. 2016. "The Foundation Phase in Wales - A Play-Based Curriculum That Supports the Development of Physical Literacy." Education 3-13 44 (5): 513-524.

Wainwright, N., J. Goodway, M. Whitehead, A. Williams, and D. Kirk. 2018. "Laying the Foundations for Physical Literacy in the Foundation Phase in Wales: The Contribution of the Foundation Phase to the Development of Physical Literacy." Physical Education and Sport Pedagogy 23 (4): 431-444.

Welsh Government. 2017. Assessing the Contribution of Schools Challenge Cyrmu to Outcomes Achieved by Pathways to Success Schools. Cardiff: Crown.

Whitehead, M. E. 2007. "Physical Literacy: Philosophical Considerations in Relation to Developing a Sense of Self, Universality and Propositional Knowledge." Sport, Ethics and Philosophy 1 (3): 281-298.

Whitehead, M. E. 2010. Physical Literacy: Throughout the Lifecourse. London: Routledge.

Williams, K. 2017. "Cabinet Secretary for Education-Written Statement: Additional Funding to Aid Transition From Schools Challenge Cymru." https://gov.wales/about/cabinet/cabinetstatements/2017/schoolschallengecymru/?lang=en.

Wood, E., and J. Attfield. 2005. Play, Learning and the Early Childhood Curriculum. London: Sage.

Wyn Siencyn, S. 2015. "Approaches to the Early Years Curriculum: A Critical View From Wales." In A Critical Companion to Early Childhood, edited by M. Reed and R. Walker, 205-216. London: Sage.

\section{Appendix}

Interview guide questions

When you went back to school, how did you feel?

What were your initial thoughts about how you were going get going?

Can you tell to me about the SKIP-Cymru sessions?

How have the children reacted to the sessions?

Have you noticed any difference in the children in class?

How have the parental engagement sessions been going?

Have you had any feedback from parents?

Can you tell me about challenges in implementing SKIP-Cymru? 